\title{
Distance-Dependent Cellular Uptake of Oligoproline-Based Homobivalent Ligands Targeting GPCRs - An Experimental and Computational Analysis
}

\author{
Stefanie Dobitz, ${ }^{\dagger}$ Patrick Wilhelm, ${ }^{\dagger}$ Nina Romantini, ${ }^{\ddagger}$ Martina De Foresta, ${ }^{\dagger}$ \\ Cornelia Walther, ${ }^{\ddagger}$ Andreas Ritler, ${ }^{\dagger \ddagger}$ Roger Schibli, ${ }^{\ddagger \|}$ Philipp Berger, ${ }^{\$}$ Xavier C. Deupi, ${ }^{\$}$ \\ Martin Béhé, ${ }^{\ddagger *}$ Helma Wennemers ${ }^{\dagger *}$ \\ ${ }^{\dagger}$ Laboratory of Organic Chemistry, D-CHAB, ETH Zurich, Vladimir-Prelog-Weg 3, 8093 Zürich, \\ Switzerland \\ ${ }^{\ddagger}$ Center for Radiopharmaceutical Sciences ETH-PSI-USZ, Paul Scherrer Institute, 5232 Villigen, \\ Switzerland \\ "Institute of Radiopharmaceutical Sciences, D-CHAB, ETH Zurich, Vladimir-Prelog-Weg 4, 8093 Zürich, \\ Switzerland \\ \$ Laboratory of Biomolecular Research and Condensed Matter Theory Group, Paul Scherrer Institute, \\ 5232 Villigen, Switzerland \\ *E-mail: martin.behe@psi.ch, helma.wennemers@org.chem.ethz.ch
}

\section{Supporting Information}




\section{Table of Contents}

1. Analytical Data of Ligands 1-5-BBN, 1-5-TOC, and Synthetic Intermediates S3

2. In vitro Studies $\quad \mathrm{S14}$

2.1 Statistical Analysis of the in vitro Evaluation of the Bombesin-Based

Ligands $\quad S 14$

2.2 Statistical Analysis of the in vitro Evaluation of the Somatostatin-Based Ligands $\quad \mathrm{S} 14$

3. ERK Phosphorylation Assays $\quad$ S16

4. In Vivo Studies $\quad$ S20 


\section{Analytical Data of Ligands 1-5-BBN, 1-5-TOC, and Synthetic Intermediates}

Alkynylated Bombesin-Based Recognition Motif

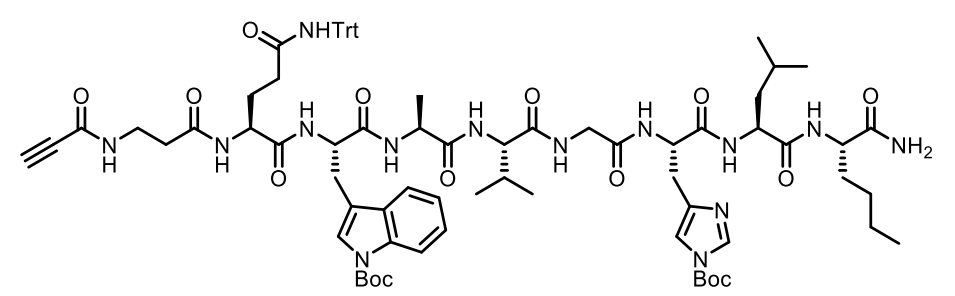

The analytical data are in agreement with previously published data (ref. 16).

\section{Alkynylated Somatostatin-Based Recognition Motif}

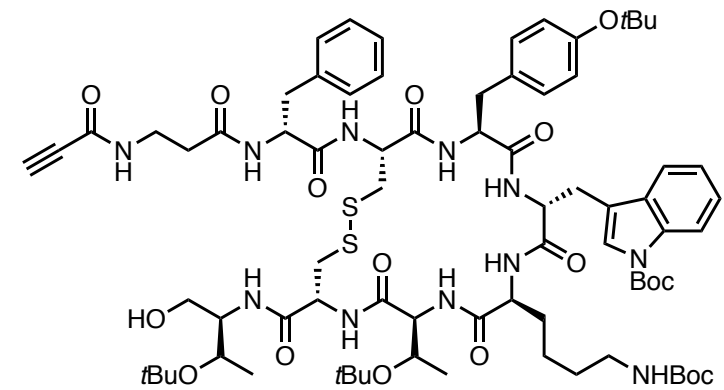

LC-ESI-MS: $\quad$ Reprosil Gold C18, $3 \mu \mathrm{m},(125 \times 3) \mathrm{mm},(95-5) \%$ B in $15 \mathrm{~min}, 0.5 \mathrm{~mL} / \mathrm{min}$, $50{ }^{\circ} \mathrm{C}$

$\mathrm{m} / \mathrm{z}$ : calcd for $\mathrm{C}_{77} \mathrm{H}_{113} \mathrm{~N}_{11} \mathrm{O}_{17} \mathrm{~S}_{2}{ }^{2+}[\mathrm{M}+2 \mathrm{H}]^{2+} 763.9$, found 764.0; calcd for $\mathrm{C}_{77} \mathrm{H}_{112} \mathrm{~N}_{11} \mathrm{O}_{17} \mathrm{~S}_{2}^{+}[\mathrm{M}+\mathrm{H}]^{+}$1526.7, found 1527.4.

Analytical HPLC: $\quad$ Reprosil Gold C18, $5 \mu \mathrm{m},(150 \times 4) \mathrm{mm},(95-5) \%$ B in $20 \mathrm{~min}, 1.0 \mathrm{~mL} / \mathrm{min}$, $50{ }^{\circ} \mathrm{C}$

$R_{t}=18.2 \min$, purity: $91 \%$

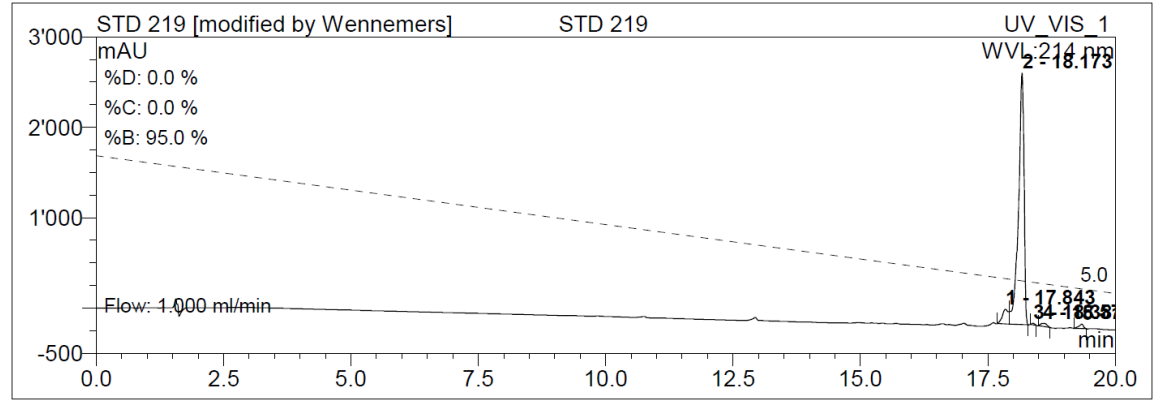




\section{Monovalent Ligand 5-BBN}

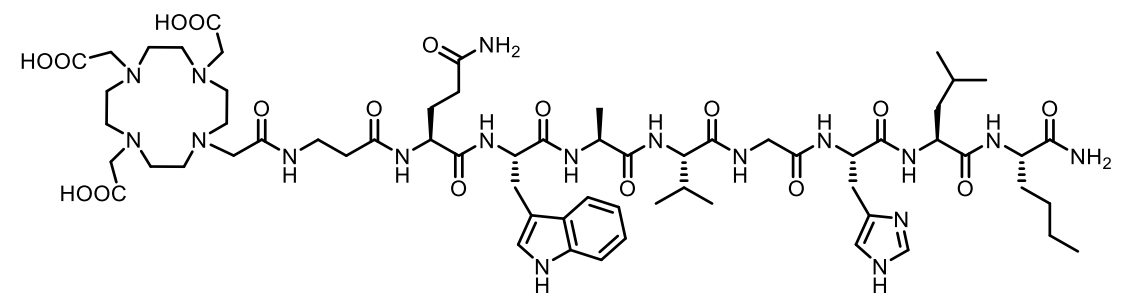

HR-MS (MALDI): $\quad \mathrm{m} / \mathrm{z}$ : calcd for $\mathrm{C}_{63} \mathrm{H}_{99} \mathrm{~N}_{18} \mathrm{O}_{17}{ }^{+}[\mathrm{M}+\mathrm{H}]^{+}$1379.7430, found 1379.7429.

Analytical HPLC: $\quad$ Reprosil Gold C18, $5 \mu \mathrm{m},(150 \times 4) \mathrm{mm},(95-50) \%$ B in $20 \mathrm{~min}, 1.0 \mathrm{~mL} / \mathrm{min}$, $50{ }^{\circ} \mathrm{C}$

$R_{t}=12.4 \min$, purity: $>99 \%$

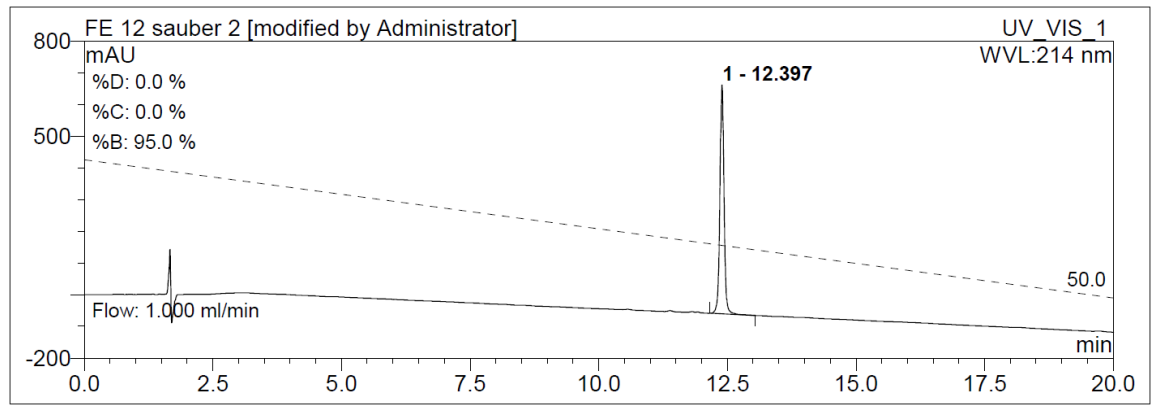




\section{Monovalent Ligand 5-TOC}

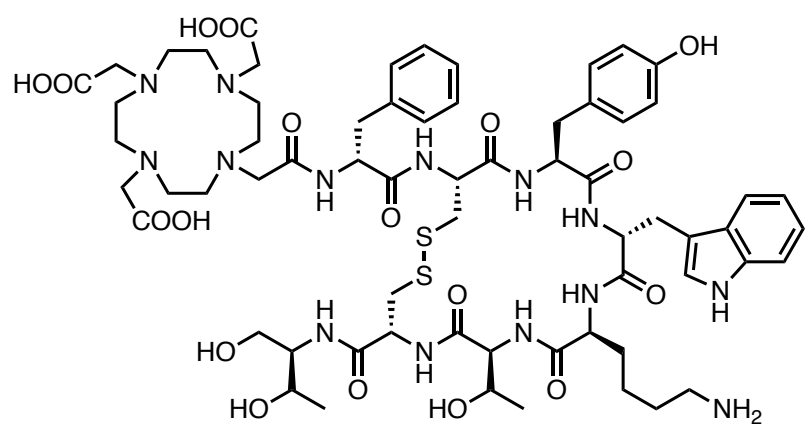

HR-MS (MALDI): $\quad \mathrm{m} / \mathrm{z}$ : calcd for $\mathrm{C}_{65} \mathrm{H}_{92} \mathrm{~N}_{14} \mathrm{O}_{18} \mathrm{~S}_{2}{ }^{+}[\mathrm{M}+\mathrm{H}]+1421.6228$, found 1421.6237.

Analytical HPLC: $\quad$ Reprosil Gold C18, $3 \mu \mathrm{m},(90-40) \%$ B in $15 \mathrm{~min}, 0.5 \mathrm{~mL} / \mathrm{min}, 50{ }^{\circ} \mathrm{C}$

$R_{t}=6.2$ min, purity: $>95 \%$

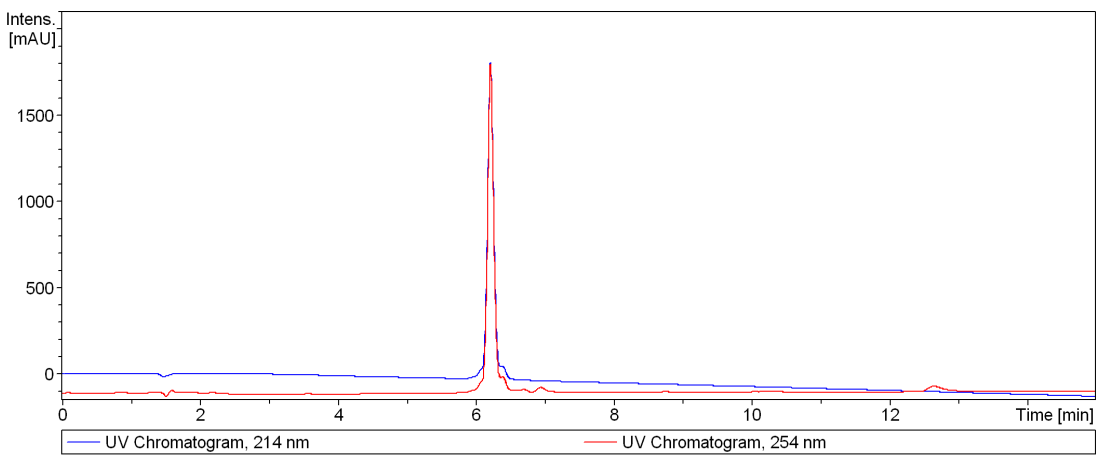

Note, either synthetic or medicinal grade purchased DOTA-TOC was used. 
Monovalent Ligand 4-BBN

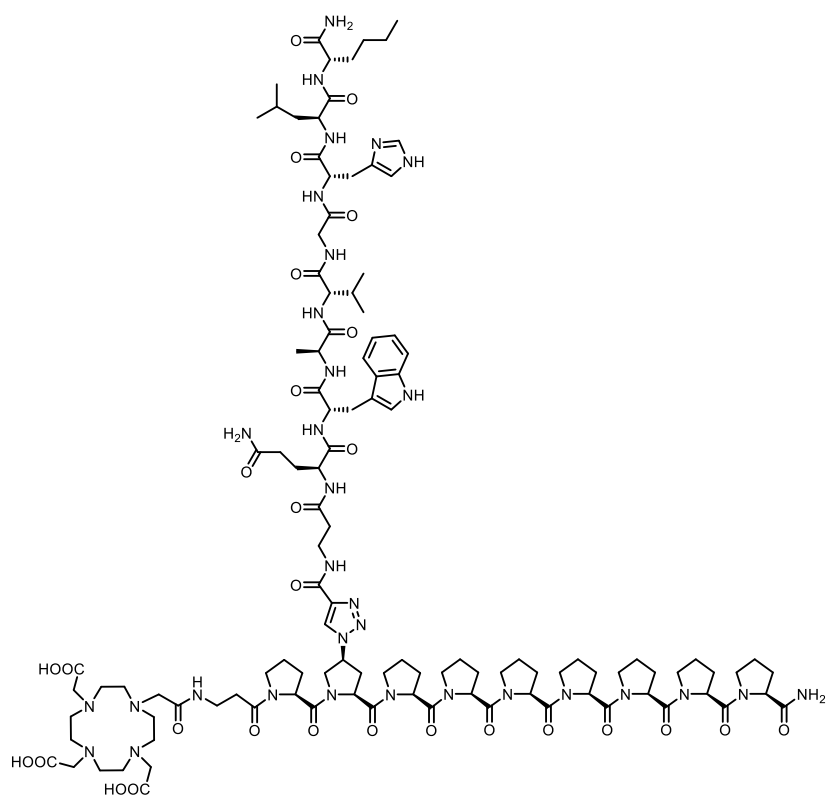

The analytical data are in agreement with previously published data (ref 16). 


\section{Monovalent Ligand 4-TOC}

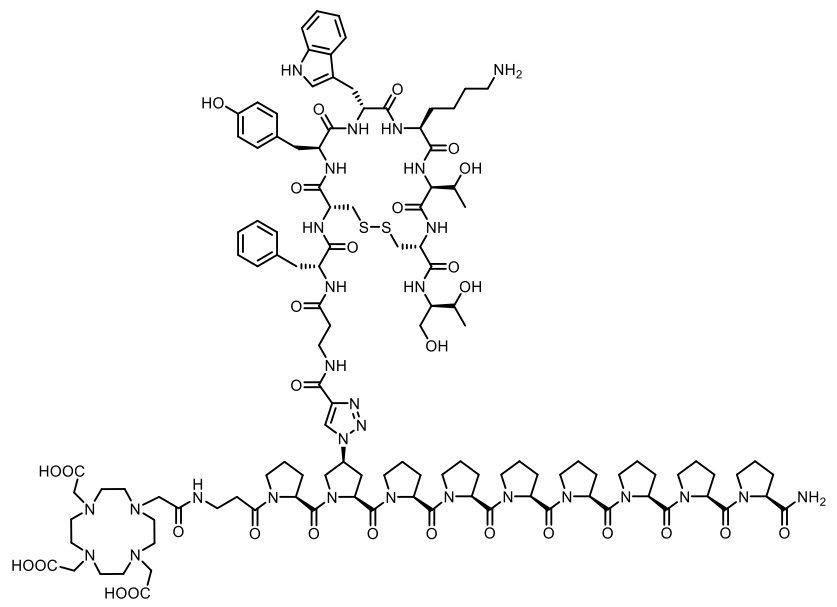

HR-MS (MALDI): $\quad \mathrm{m} / \mathrm{z}$ : calcd for $\mathrm{C}_{119} \mathrm{H}_{168} \mathrm{~N}_{29} \mathrm{O}_{30} \mathrm{~S}_{2}^{+}[\mathrm{M}+\mathrm{H}]^{+}$2547.1948, found 2547.2003.

Analytical HPLC: Reprosil Gold C18, $5 \mu \mathrm{m},(150 \times 4) \mathrm{mm},(95-55) \%$ B in $20 \mathrm{~min}, 1.0 \mathrm{~mL} / \mathrm{min}$, $50{ }^{\circ} \mathrm{C}$

$R_{t}=12.6 \min$, purity: $>99 \%$

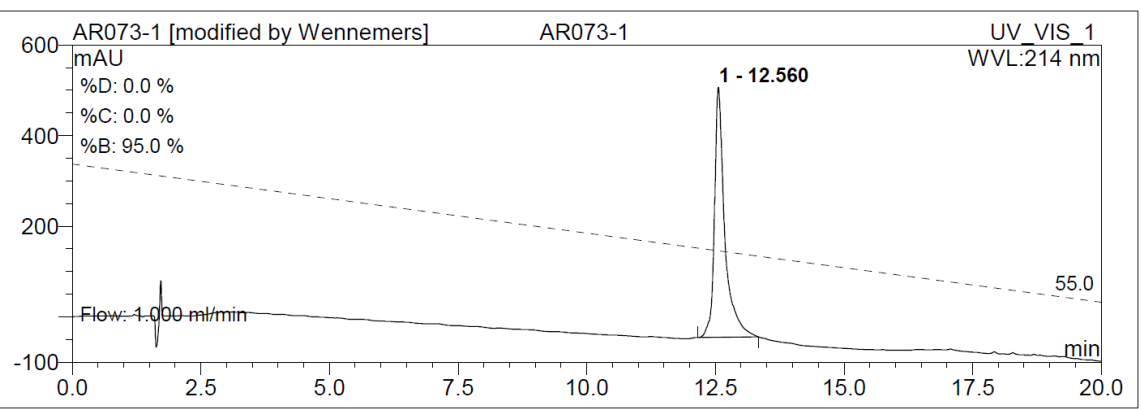




\section{A Homobivalent Ligand 1-BBN}

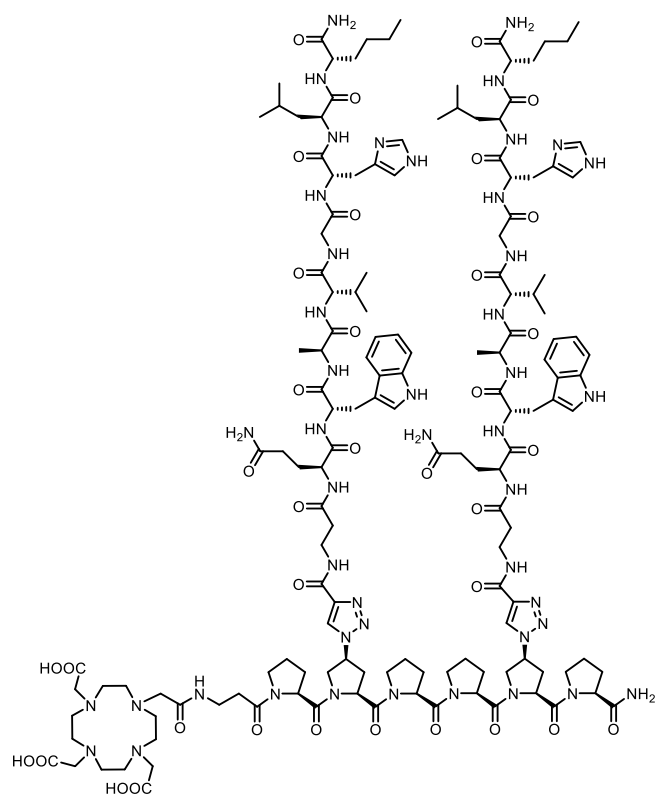

HR-MS (MALDI): $\quad \mathrm{m} / \mathrm{z}$ : calcd for $\mathrm{C}_{149} \mathrm{H}_{219} \mathrm{~N}_{46} \mathrm{O}_{36}{ }^{+}[\mathrm{M}+\mathrm{H}]^{+}$3228.6715, found 3228.6682; calcd for $\mathrm{C}_{149} \mathrm{H}_{218} \mathrm{~N}_{46} \mathrm{NaO}_{36}{ }^{+}[\mathrm{M}+\mathrm{Na}]^{+} 3250.6534$, found 3250.6535 .

Analytical HPLC: $\quad$ Reprosil Gold C18, $5 \mu \mathrm{m},(150 \times 4) \mathrm{mm},(95-50) \%$ B in $20 \mathrm{~min}, 1.0 \mathrm{~mL} / \mathrm{min}$, $50{ }^{\circ} \mathrm{C}$

$R_{t}=15.2 \min$, purity: $96 \%$

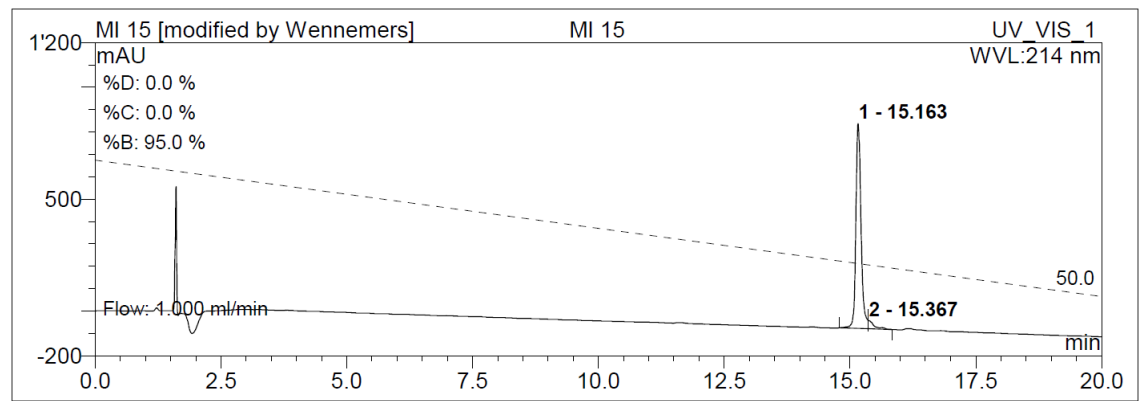


20 A Homobivalent Ligand 2-BBN

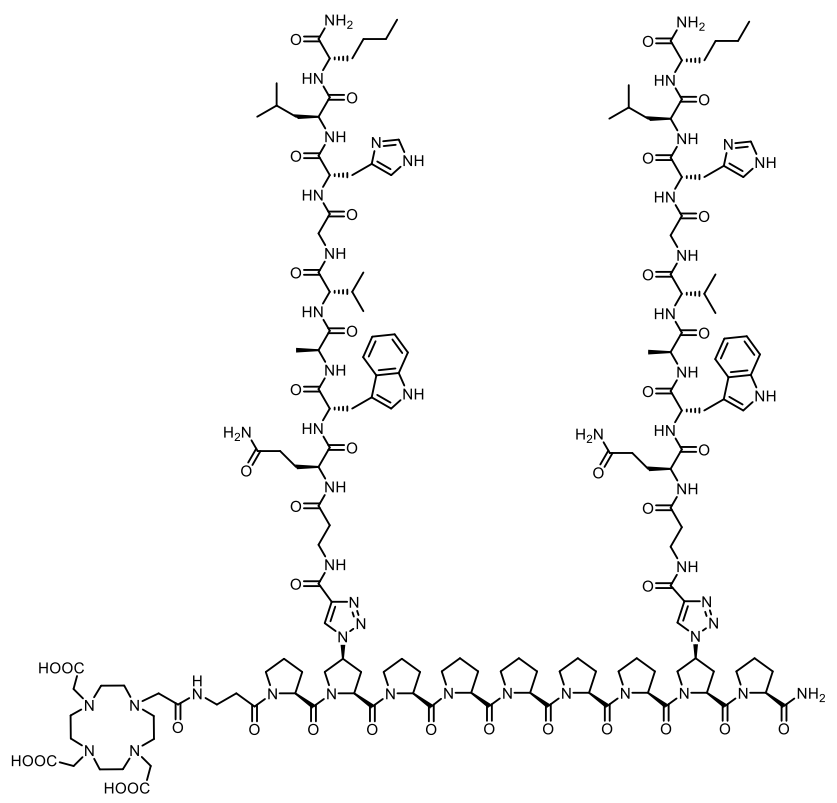

The analytical data are in agreement with previously published data (ref 16). 
30 A Homobivalent Ligand 3-BBN

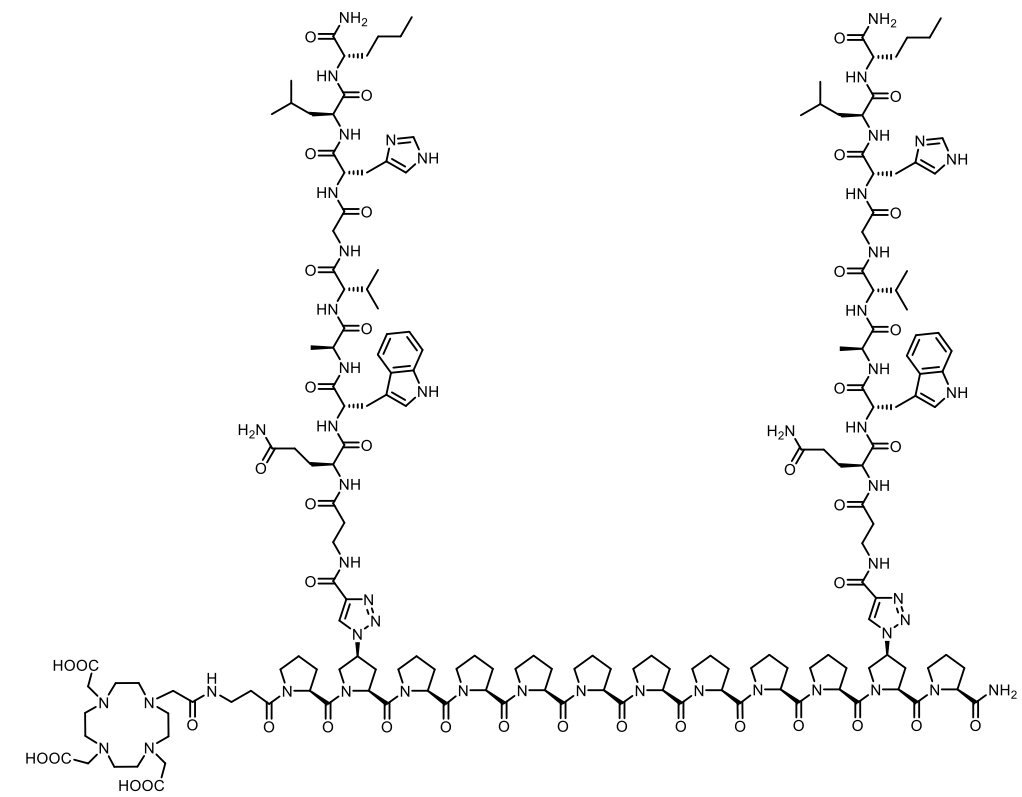

HR-MS (MALDI): $\quad \mathrm{m} / \mathrm{z}$ : calcd for $\mathrm{C}_{179} \mathrm{H}_{261} \mathrm{~N}_{52} \mathrm{O}_{42}{ }^{+}[\mathrm{M}+\mathrm{H}]^{+}$3810.9880, found 3810.9813; calcd for $\mathrm{C}_{179} \mathrm{H}_{260} \mathrm{~N}_{52} \mathrm{NaO}_{42}{ }^{+}[\mathrm{M}+\mathrm{Na}]^{+} 3832.9700$, found 3832.9667 .

Analytical HPLC: $\quad$ Phenomenex Jupiter C18 $300 \AA, 5 \mu \mathrm{m},(250 \times 4.6) \mathrm{mm},(95-50) \%$ in $20 \mathrm{~min}, 1.0 \mathrm{~mL} / \mathrm{min}, 50^{\circ} \mathrm{C}$

$R_{t}=17.1$ min, purity: $99 \%$

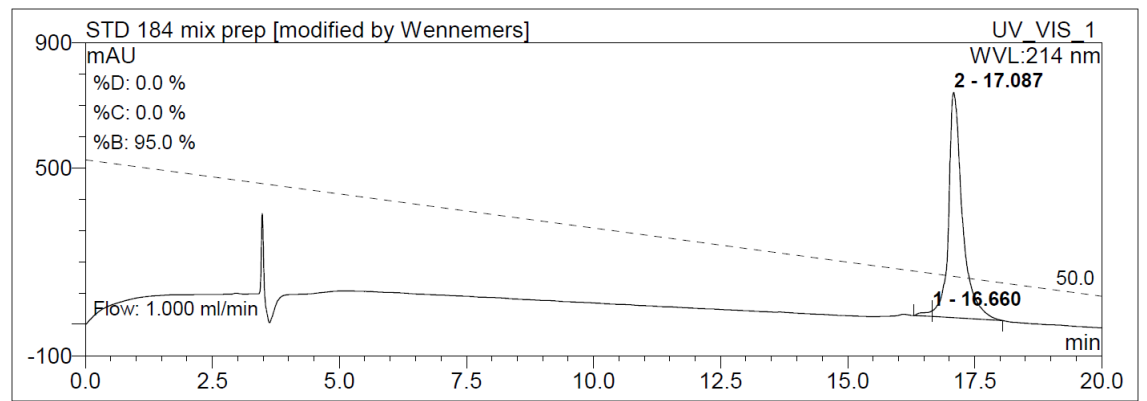




\section{A Homobivalent Ligand 1-TOC}

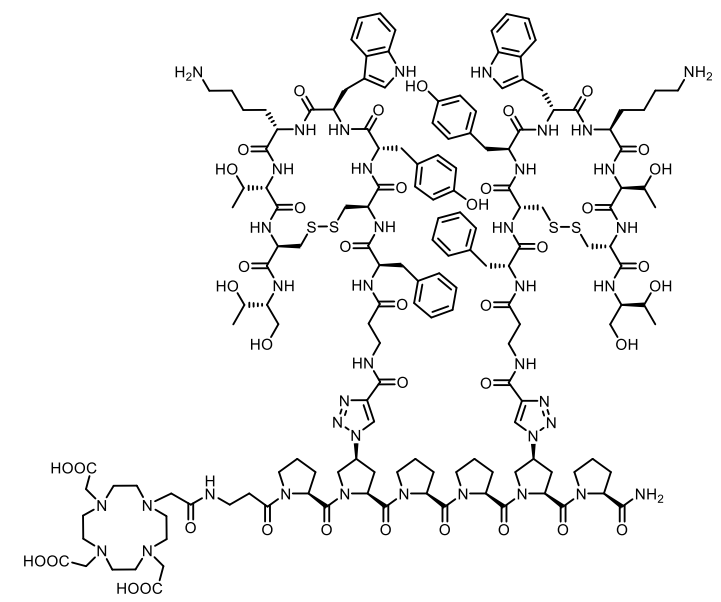

HR-MS (MALDI): $\quad \mathrm{m} / \mathrm{z}$ : calcd for $\mathrm{C}_{159} \mathrm{H}_{217} \mathrm{~N}_{40} \mathrm{O}_{40} \mathrm{~S}_{4}{ }^{+}[\mathrm{M}+\mathrm{H}]^{+}$3454.5053, found 3454.4954; calcd for $\mathrm{C}_{159} \mathrm{H}_{216} \mathrm{~N}_{40} \mathrm{NaO}_{40} \mathrm{~S}_{4}^{+}[\mathrm{M}+\mathrm{Na}]^{+} 3476.4872$, found 3476.4761 .

Analytical HPLC: $\quad$ Reprosil $100 \mathrm{C} 18,5 \mu \mathrm{m},(150 \times 4) \mathrm{mm},(95-50) \%$ B in $20 \mathrm{~min}, 1.0 \mathrm{~mL} / \mathrm{min}$, $50{ }^{\circ} \mathrm{C}$

$R_{t}=13.2$ min, purity: $99 \%$

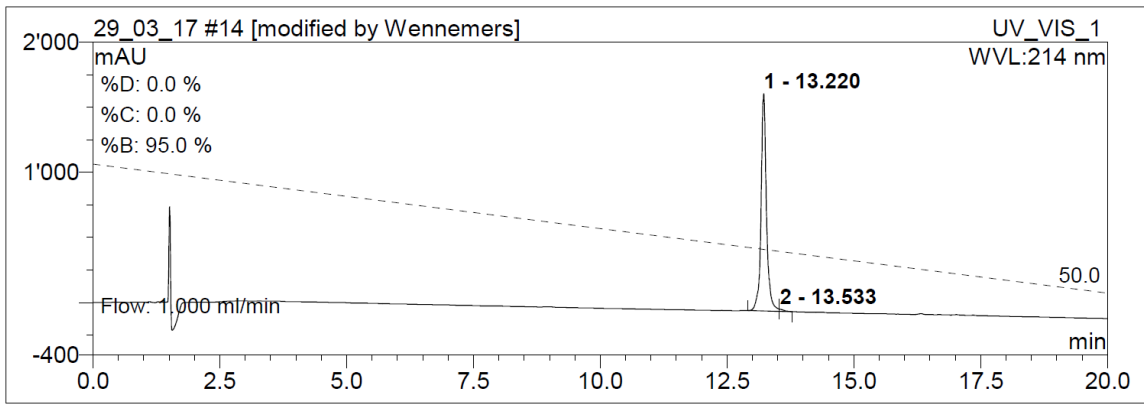


20 A Homobivalent Ligand 2-TOC

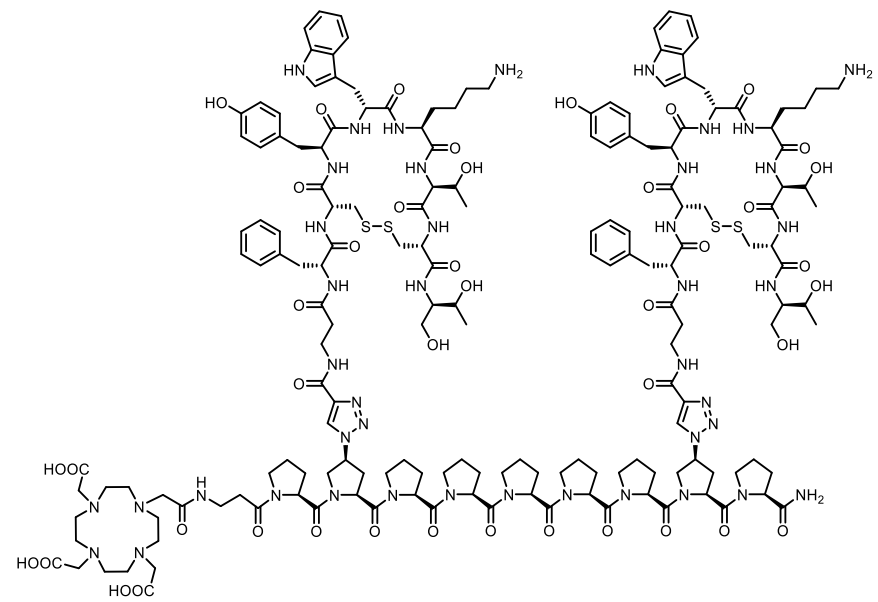

HR-MS (MALDI): $\quad \mathrm{m} / \mathrm{z}$ : calcd for $\mathrm{C}_{174} \mathrm{H}_{238} \mathrm{~N}_{43} \mathrm{O}_{43} \mathrm{~S}_{4}{ }^{+}[\mathrm{M}+\mathrm{H}]^{+}$3745.6636, found 3745.6635; calcd for $\mathrm{C}_{174} \mathrm{H}_{237} \mathrm{~N}_{43} \mathrm{NaO}_{43} \mathrm{~S}_{4}{ }^{+}[\mathrm{M}+\mathrm{Na}]^{+} 3767.6455$, found 3767.6467 .

Analytical HPLC: $\quad$ Phenomenex Jupiter C18 $300 \AA, 5 \mu \mathrm{m},(250 \times 4.6) \mathrm{mm},(95-50) \%$ B in $20 \mathrm{~min}, 1.0 \mathrm{~mL} / \mathrm{min}, 50^{\circ} \mathrm{C}$

$R_{t}=15.6$ min, purity: $86 \%$

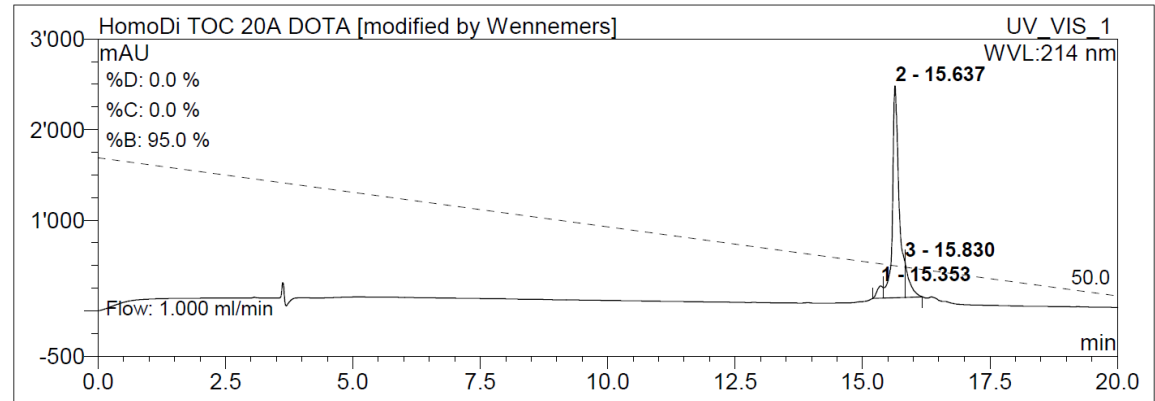

Note, after radiolabeling with LU-177 a major radiolabeled species was detected by HPLC:

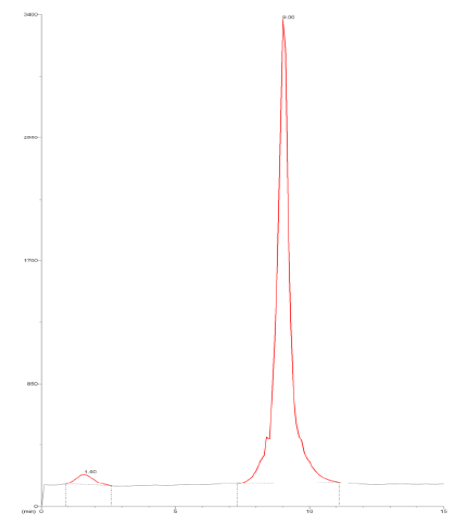

1.6 min: free Lu-177 (3\%)

9.0 min: Lu-177 2-TOC (97\%) 
30 A Homobivalent Ligand 3-TOC

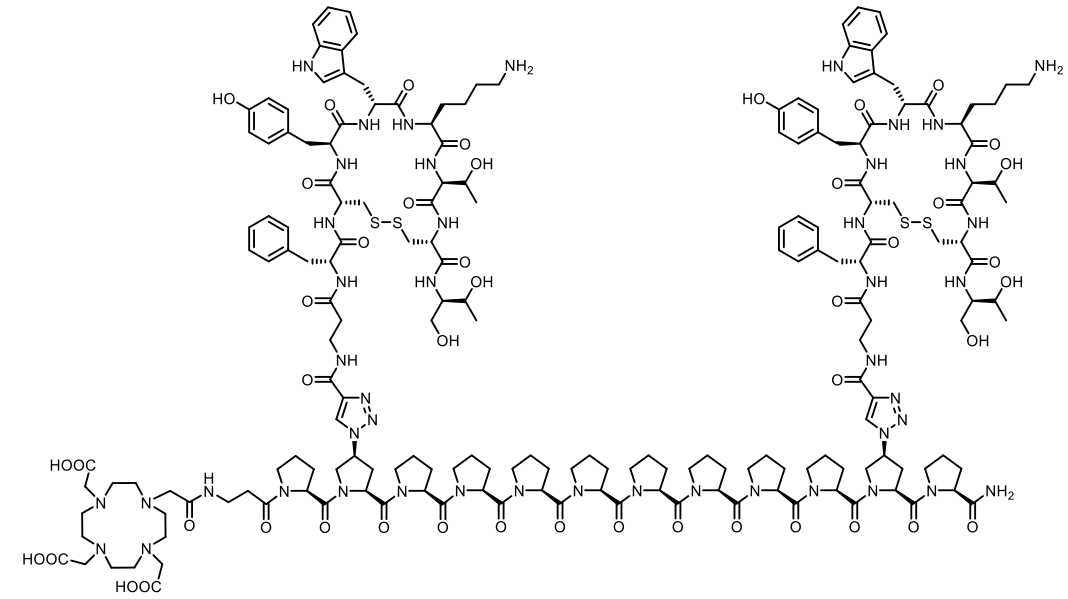

HR-MS (MALDI): $\quad \mathrm{m} / \mathrm{z}$ : calcd for $\mathrm{C}_{189} \mathrm{H}_{259} \mathrm{~N}_{46} \mathrm{O}_{46} \mathrm{~S}_{4}{ }^{+}[\mathrm{M}+\mathrm{H}]^{+}$4036.8219, found 4036.8371; calcd for $\mathrm{C}_{189} \mathrm{H}_{258} \mathrm{~N}_{46} \mathrm{NaO}_{46} \mathrm{~S}_{4}{ }^{+}[\mathrm{M}+\mathrm{Na}]^{+} 4058.8038$, found 4058.8128 .

Analytical HPLC: $\quad$ Phenomenex Jupiter C18 $300 \AA, 5 \mu \mathrm{m},(250 \times 4.6) \mathrm{mm},(95-50) \%$ B in $20 \mathrm{~min}, 1.0 \mathrm{~mL} / \mathrm{min}, 50^{\circ} \mathrm{C}$

$R_{t}=13.7$ min, purity: $85 \%$

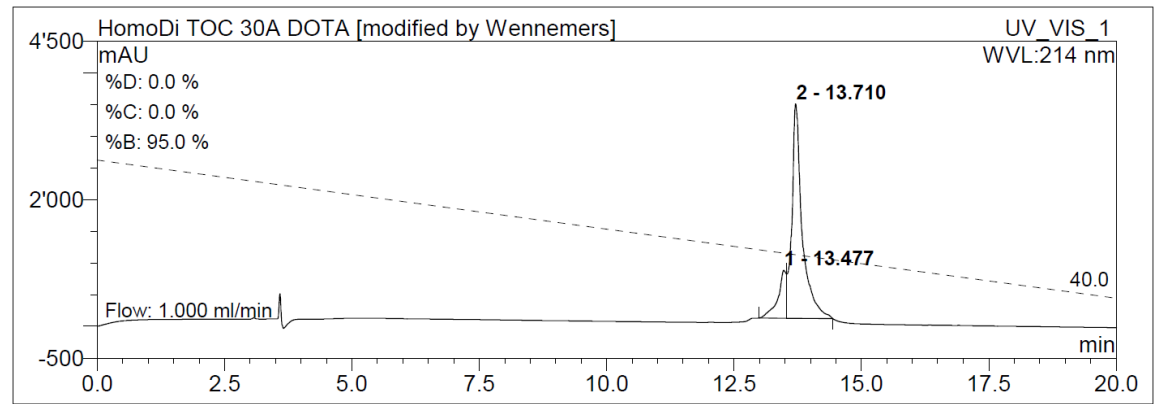

Note, after radiolabeling with LU-177 a major radiolabeled species was detected by HPLC.

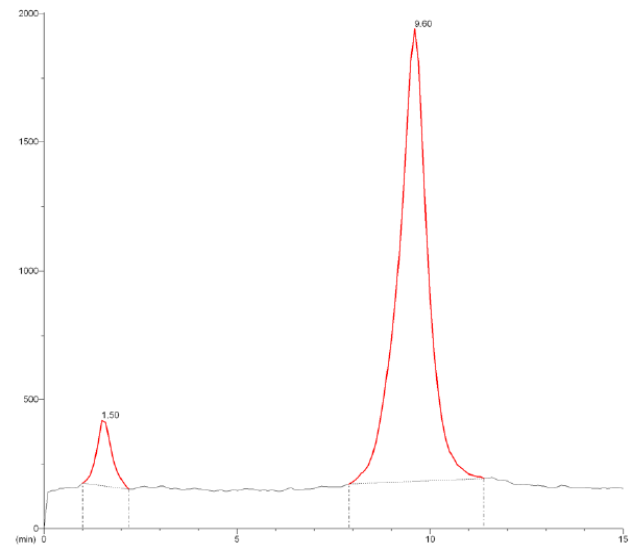

1.5 min: free $L u-177$ (7\%)

9.6 min: Lu-177 3-TOC (93\%) 


\section{In vitro Studies}
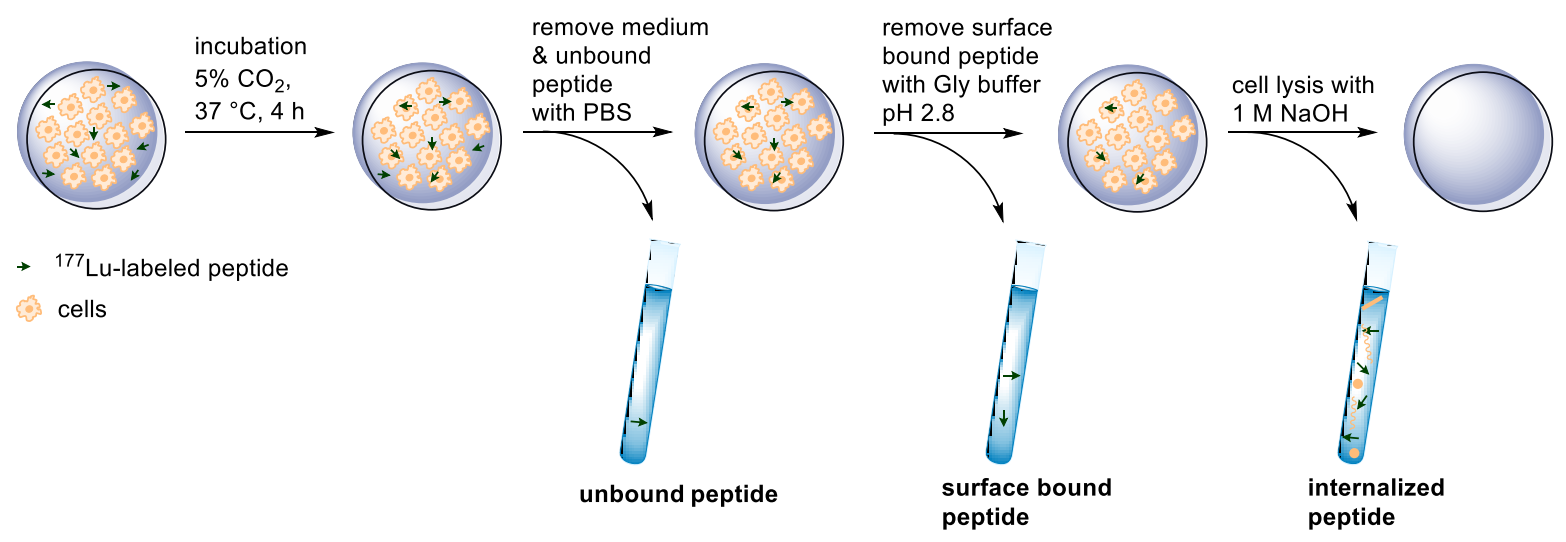

Figure S1 Work flow of the in vitro internalization assays. Note, we used an incubation time of $4 \mathrm{~h}$ for the comparison of the different ligands because time-course experiments showed a plateau at this time

\section{Statistical Analysis of the in vitro Evaluation of the Bombesin-Based Ligands}

Table S1 Statistical analysis of the in vitro cellular uptake of the ${ }^{177}$ Lu-labeled, bombesin-based agonistic ligands in HEK-hGRP-R cells after $4 \mathrm{~h}$ of incubation with 1way ANOVA and Tukey's multiple comparisons test.

\begin{tabular}{ccc}
\hline Tukey's multiple comparisons test & Summary & p Value \\
\hline 1-BBN vs. 2-BBN & $n s$ & $>0,9999$ \\
\hline 1-BBN vs. 3-BBN & $n s$ & 0.0501 \\
\hline 1-BBN vs. 4-BBN & $* * *$ & $<0,0001$ \\
\hline 1-BBN vs. 5-BBN & $* * * *$ & $<0,0001$ \\
\hline 2-BBN vs. 3-BBN & $*$ & 0.021 \\
\hline 2-BBN vs. 4-BBN & $* * *$ & $<0,0001$ \\
\hline 2-BBN vs. 5-BBN & $* * * *$ & $<0,0001$ \\
\hline 3-BBN vs. 4-BBN & $* *$ & 0.0018 \\
\hline 3-BBN vs. 5-BBN & $*$ & 0.0216 \\
\hline 4-BBN vs. 5-BBN & ns & 0.4463 \\
\hline
\end{tabular}




\section{Statistical Analysis of the in vitro Evaluation of the Somatostatin-Based Ligands}

Table S2 Statistical analysis of the in vitro cellular uptake of the ${ }^{177}$ Lu-labeled, somatostatin-based agonistic ligands in $\mathrm{CHO}-\mathrm{hSstR}{ }_{2 a}$ cells after $4 \mathrm{~h}$ of incubation with 1 way ANOVA and Tukey's multiple comparisons test.

\begin{tabular}{ccc}
\hline Tukey's multiple comparisons test & Summary & p Value \\
\hline 1-TOC vs. 2-TOC & $n s$ & 0.1069 \\
1-TOC vs. 3-TOC & $n s$ & $>0,9999$ \\
1-TOC vs. 4-TOC & $n s$ & 0.9939 \\
1-TOC vs. 5-TOC & $n s$ & $>0,9999$ \\
2-TOC vs. 3-TOC & $*$ & 0.0206 \\
2-TOC vs. 4-TOC & $* *$ & 0.0073 \\
2-TOC vs. 5-TOC & $* *$ & 0.0048 \\
3-TOC vs. 4-TOC & ns & 0.9948 \\
3-TOC vs. 5-TOC & ns & $>0,9999$ \\
1-TOC vs. 2-TOC & ns & 0.1069 \\
\hline
\end{tabular}




\section{ERK Phosphorylation Assays}

\section{Experimental Method}

One day before the experiment, HEK-hGRP-R and CHO-hSstR 2a $_{2}$ cells $\left(5 \cdot 10^{5}\right.$ per well) were suspended in DMEM or Ham`s F12 (1 mL, 10\% FCS), seeded into poly-L-lysine coated or uncoated 6-well plates, and allowed to adhere overnight, respectively. On the day of the experiment, the culture medium was aspirated. Warmed reduced serum medium (Opti-MEM ${ }^{\mathrm{TM}}$,

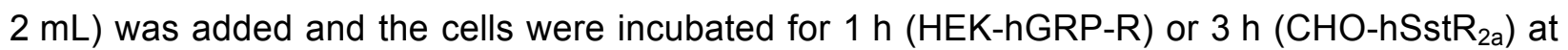
$37^{\circ} \mathrm{C}\left(5 \% \quad \mathrm{CO}_{2}\right.$, humidified atmosphere). Opti-MEM ${ }^{\mathrm{TM}}$ was aspirated and the cells were incubated with $10 \mathrm{nM}$ of the corresponding ligand in Opti-MEM ${ }^{\mathrm{TM}}(2 \mathrm{~mL})$ for the indicated amount of time $\left(5 \% \mathrm{CO}_{2}, 37^{\circ} \mathrm{C}\right)$. Afterwards, the cells were put on ice and washed with ice cold PBS (2x $5 \mathrm{~mL}$ ). Lysis buffer containing protease and phosphatase inhibitors was added $(150 \mu \mathrm{L})$ and the cells were rocked on ice for $20 \mathrm{~min}$. The protease inhibitor cocktail consisted of cOmplete $^{\mathrm{TM}}$ Mini EDTA free $(1$ tablet $/ 10 \mathrm{~mL})$ and phosphatase inhibitors $\mathrm{NaF}(10 \mathrm{mM})$ and $\mathrm{Na}_{3} \mathrm{VO}_{4}(1 \mathrm{mM})$. Next, the cells were scraped from the dish and transferred to Eppendorf $\circledast$ microcentrifuge tubes. Insoluble material was pelleted by centrifugation and the supernatant was transferred into clean tubes. The protein concentration of the cell lysate was determined with the Pierce ${ }^{T M}$ BCA protein assay. The appropriate volume of $3 x$ reduced sodium dodecyl sulfate (SDS) buffer (containing 15\% $\quad \beta$-mercaptoethanol) was added to give a final concentration that is within the dynamic range of the detection and heated to $50{ }^{\circ} \mathrm{C}$ for $30 \mathrm{~min}$. Next, the gels for SDS-PAGE were prepared: a polyacrylamide separating (10\% acrylamide) and stacking gel (4\% acrylamide). Samples were loaded and the gel was run for 20 min at $90 \mathrm{~V}$ and $(1-1.5) \mathrm{h}$ at $150 \mathrm{~V}$. Afterwards, the separated proteins were transferred onto a polyvinylidene difluoride (PVDF) membrane with a semi-dry blotter (Trans-Blot Turbo Transfer System, Bio-Rad) at $25 \mathrm{~V}$ for $(20-25) \mathrm{min}$. For the Western Blot analysis of the transferred proteins, non-specific sites were blocked with $5 \%$ bovine serum albumin (BSA) in TBS-T (tris(hydroxymethyl)-aminomethane (TRIS)-buffered saline containing 0.05\% Tween-20) for $3 x$ $10 \mathrm{~min}$ at rt on an orbital shaker. The blocking buffer was removed and the primary antibody in TBS-T containing $(2.5-5) \%$ BSA was incubated overnight at $4{ }^{\circ} \mathrm{C}$. The primary antibodies were p44/42 MAPK (Erk1/2) antibody (no. 9102), dilution $1: 1.000$, for the detection of total ERK and phospho-p44/42 MAPK (Erk1/2) (Thr202/Tyr204) (E10) mouse mAb (no. 9106), dilution $1: 2.000$, for the detection of phosphorylated ERK (both Cell Signaling Technology). Afterwards, the primary antibody solution was removed and the PVDF membrane was washed with TBS-T for $10 \mathrm{~min}$ at rt on an orbital shaker. Next, the AP-conjugated secondary antibody solution was added in TBS-T containing $(2.5-5) \%$ BSA and incubated for $1 \mathrm{~h}$ at $\mathrm{rt}$ on an orbital shaker. The 
secondary antibodies were donkey anti-rabbit $\lg G(H+L) ~ M s / R t / H m$ SP ads-AP (no. 241), dilution $1: 10.000$, for the detection of the primary antibody for total ERK and goat anti-mouse IgG $(\mathrm{H}+\mathrm{L})-A P$ (no. 188), dilution 1:5.000, for the detection of the primary antibody for phosphorylated ERK (both Southern Biotech). Afterwards, the PVDF membranes were washed as described above and additionally washed with distilled $\mathrm{H}_{2} \mathrm{O}(2 \mathrm{x})$. Subsequently, the PVDF membrane was incubated with Novex AP Chemiluminescent Substrate for $1 \mathrm{~min}$ at rt. Then, the PVDF membrane was dried and chemoluminescence detection was performed with an Amersham Imager 600. Quantitative analysis of the gels was performed by densiometry using ImageJ (1.49v, Wayne Rasband, NIH, USA). Experiments were performed in triplicates. Evaluation and statistical analyses was performed as described above (chapter 6.1).

\section{ERK Assay of the Bombesin-Based Ligands}
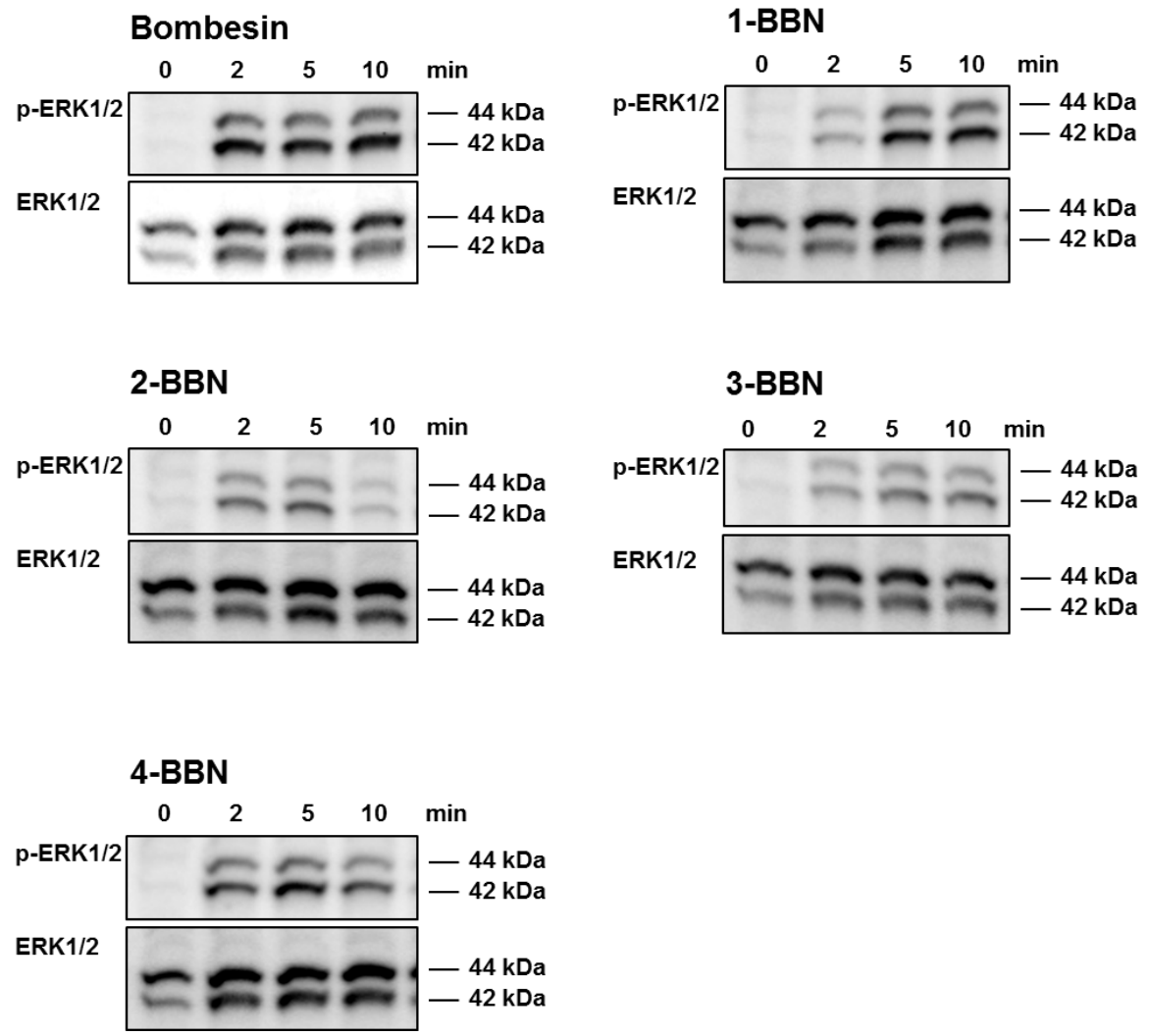

Figure S2 Representative Western blots of time-dependent ERK activation of bombesin, the bombesin-based homobivalent ligands 1-BBN - 3-BBN, and monovalent ligand 4-BBN. Experiments were performed with HEK hGRP$\mathrm{R}$ cells. 


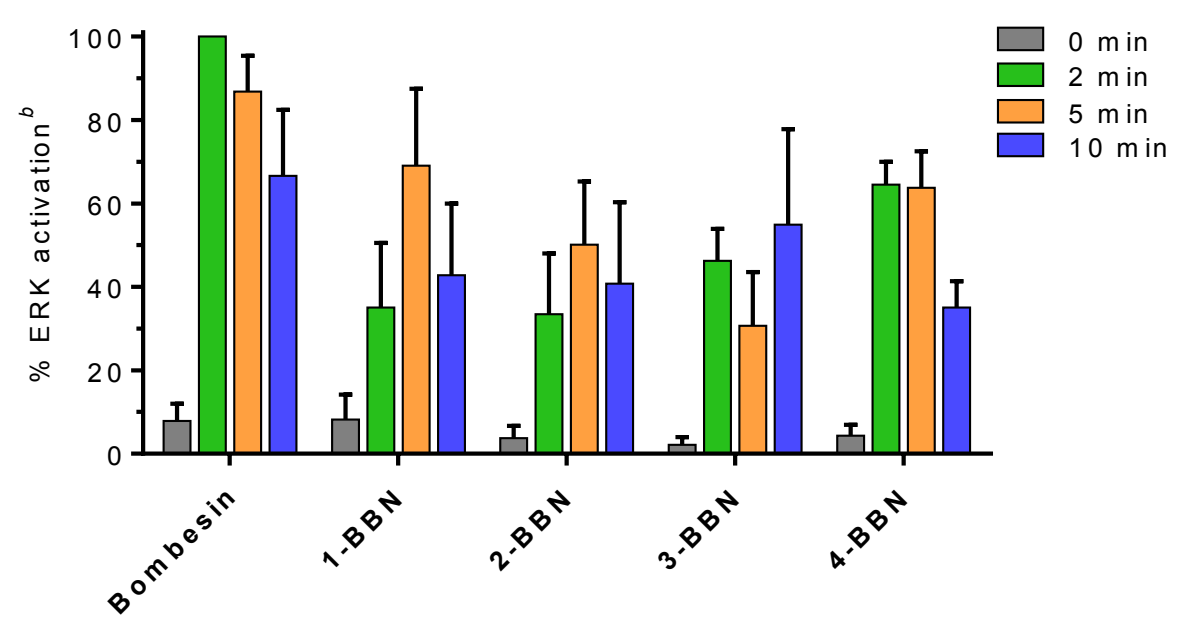

Figure S3 Western blot quantification of time-dependent ERK activation of bombesin, the bombesin-based homobivalent ligands 1-BBN - 3-BBN, and monovalent ligand 4-BBN in HEK hGRP-R cells. Values are given as mean \pm standard error of the mean (SEM). ${ }^{b}$ Normalized to maximal bombesin response.

\section{ERK Assay of the Somatostatin-Based Ligands}

\begin{tabular}{|c|c|c|c|c|c|c|c|c|c|c|}
\hline \multicolumn{4}{|c|}{ Somatostatin } & & & 1-T & & & & \multirow[b]{2}{*}{$\min$} \\
\hline & 0 & 2 & $5 \quad 10$ & $\min$ & & 0 & 2 & 5 & 10 & \\
\hline p-ERK1/2 & & 2 & $=2$ & $\begin{array}{l}-44 \mathrm{kDa} \\
-42 \mathrm{kDa}\end{array}$ & p-ERK1/2 & & & & & $\begin{array}{l}-44 \mathrm{kDa} \\
-42 \mathrm{kDa}\end{array}$ \\
\hline RK1/2 & $=$ & $\approx$ & 20 & $\begin{array}{l}-44 \mathrm{kDa} \\
-42 \mathrm{kDa}\end{array}$ & ERK1/2 & & & & & $\begin{array}{l}-44 \mathrm{kDa} \\
-42 \mathrm{kDa}\end{array}$ \\
\hline
\end{tabular}

2-TOC

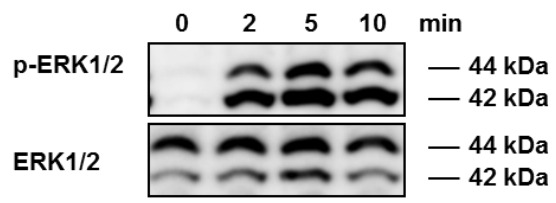

4-TOC

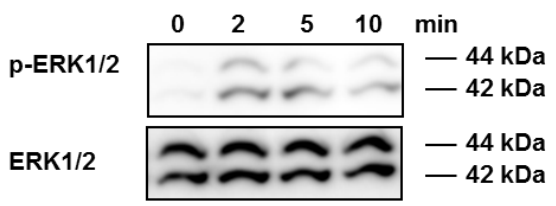

\section{3-TOC}

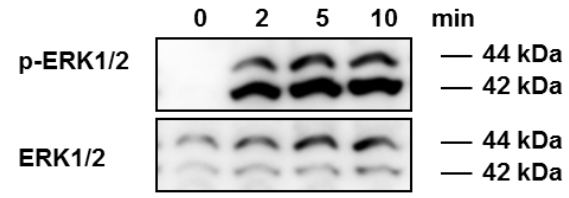

Figure S4 Representative Western blots of time-dependent ERK activation of somatostatin, the somatostatin-based homobivalent ligands 1-TOC - 3-TOC, and monovalent ligand 4-TOC. Experiments were performed with CHO-hSstR 2a cells. 


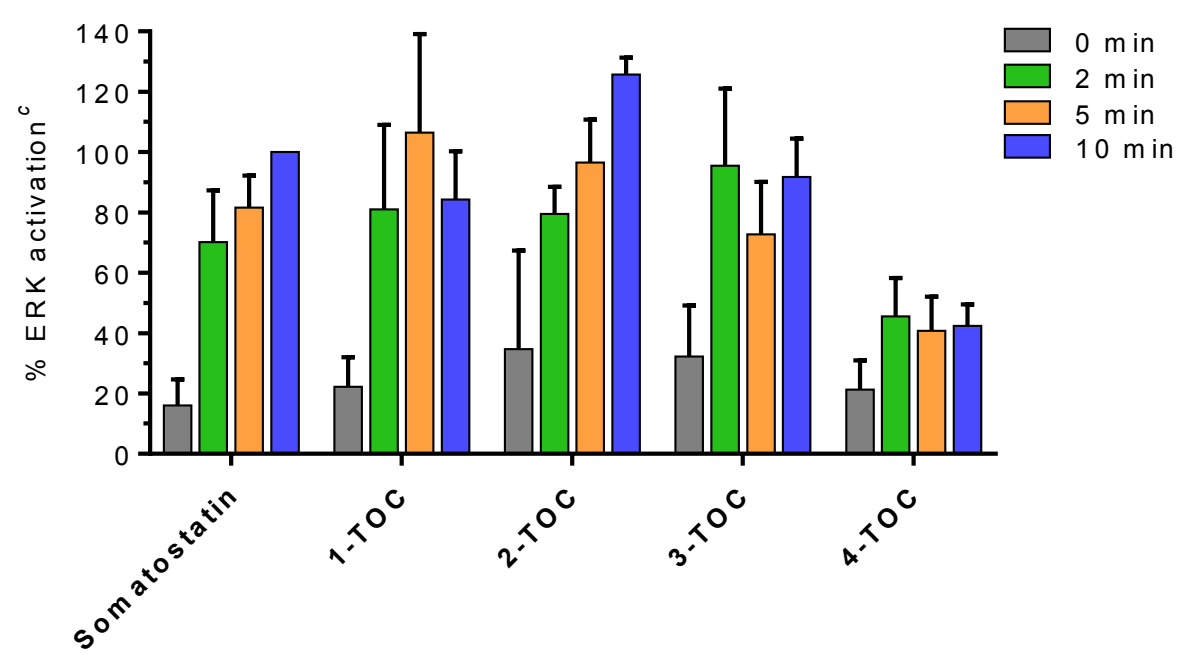

Figure S5 Western blot quantification of time-dependent ERK activation of somatostatin, the somatostatin-based homobivalent ligands 1-TOC - 3-TOC, and monovalent ligand 4-TOC in CHO-hSstR ${ }_{2 a}$ cells. Values are given as mean \pm SEM. ${ }^{c}$ Normalized to maximal somatostatin response. 


\section{In Vivo Studies}

Biodistribution of BBN-based ligands (extended graph with all examined tissues)

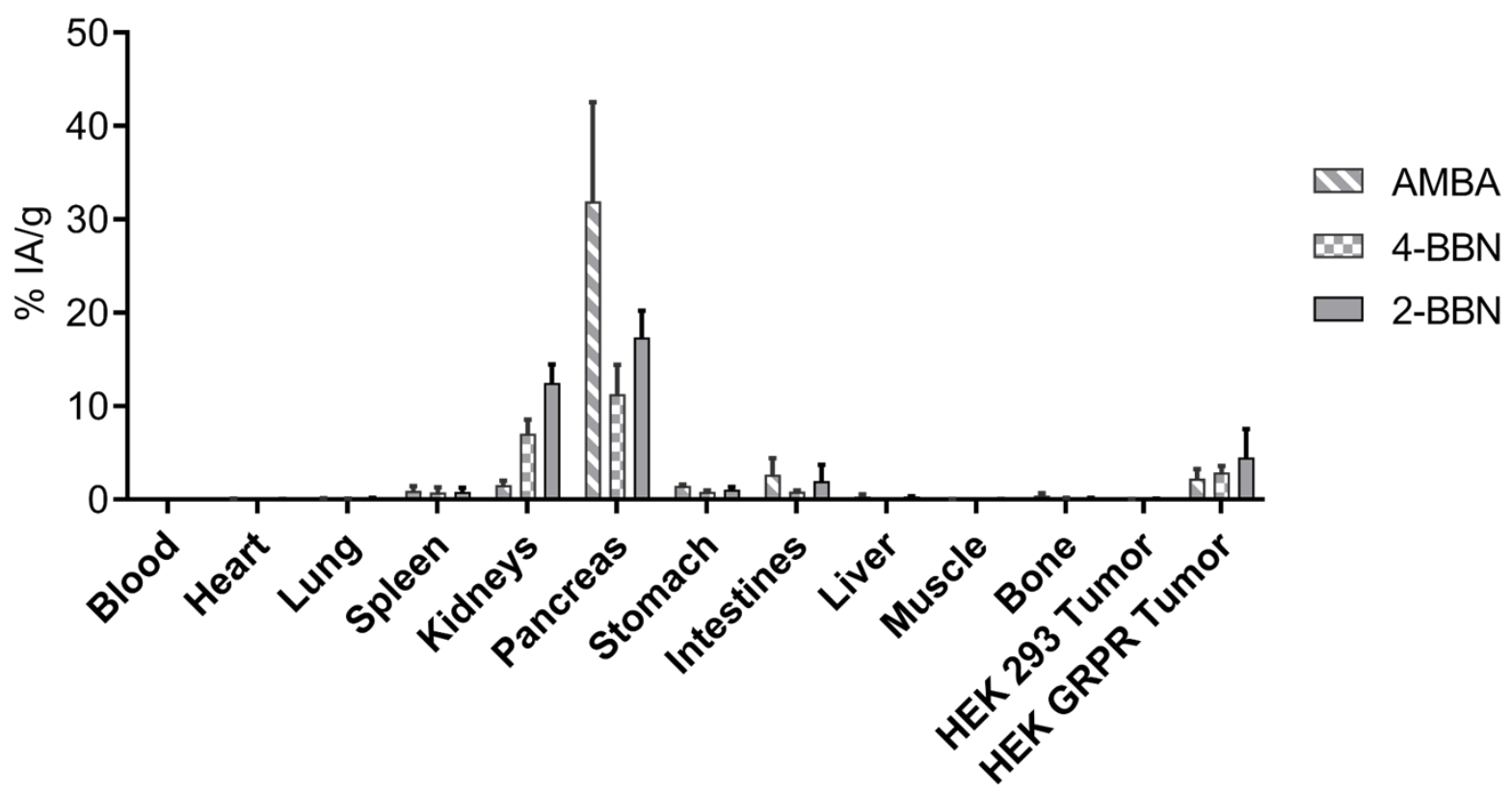

Figure S6 Biodistribution of ${ }^{177}$ Lu-labelled bombesin analogues $4 \mathrm{~h}$ post-injection in HEK-GRPR and HEK293 tumour-bearing SCID mice. The values represent the mean \pm standard deviation of at least four animals in $\%$ injected activity per gram of organ. $10 \mathrm{pmol}$ of radioligand per animal were applied by i.v. injection.
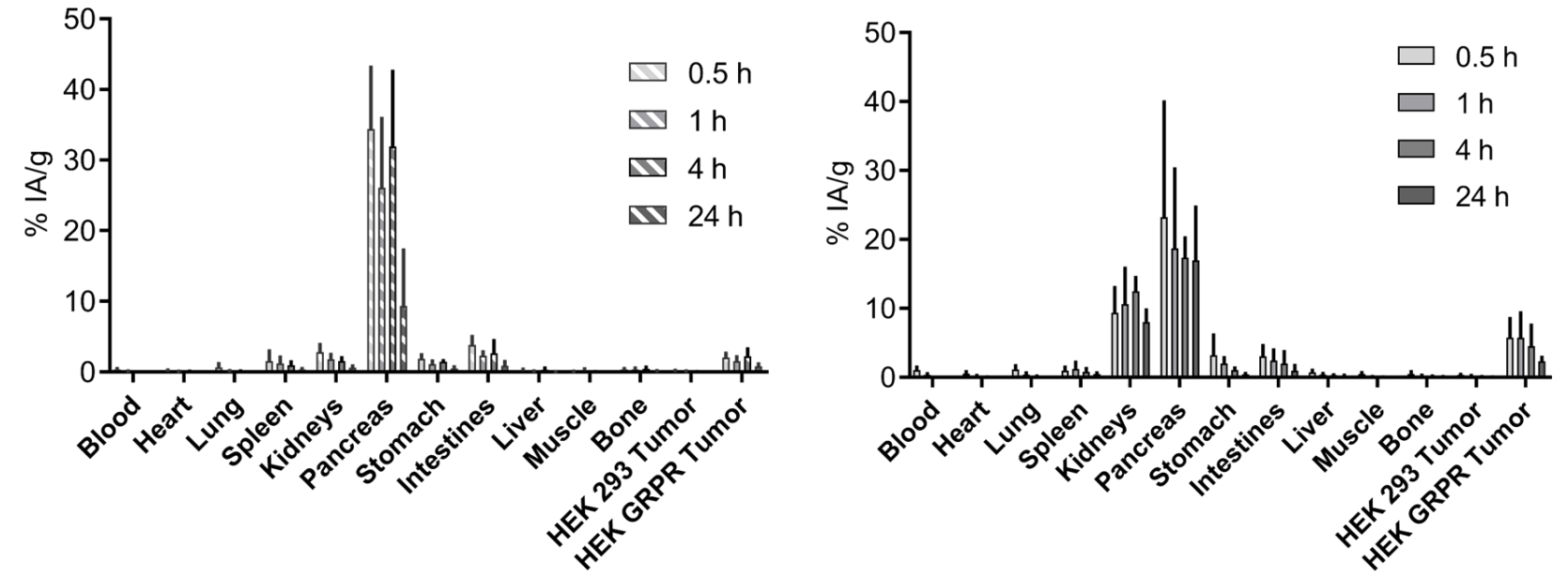

Figure S7 Biodistribution of ${ }^{177}$ Lu-labelled AMBA (left) and 2-BBN (right) $0.5 \mathrm{~h}, 1 \mathrm{~h}, 4 \mathrm{~h}$ and $24 \mathrm{~h}$ post-injection in HEK-hGRP-R and HEK293 tumour-bearing SCID mice. The values represent the mean \pm standard deviation of at least four animals in \% injected activity per gram of organ. $10 \mathrm{pmol}$ of radioligand per animal were applied by i.v. injection. 
Biodistribution of TOC-based ligands (extended graph with all examined tissues)

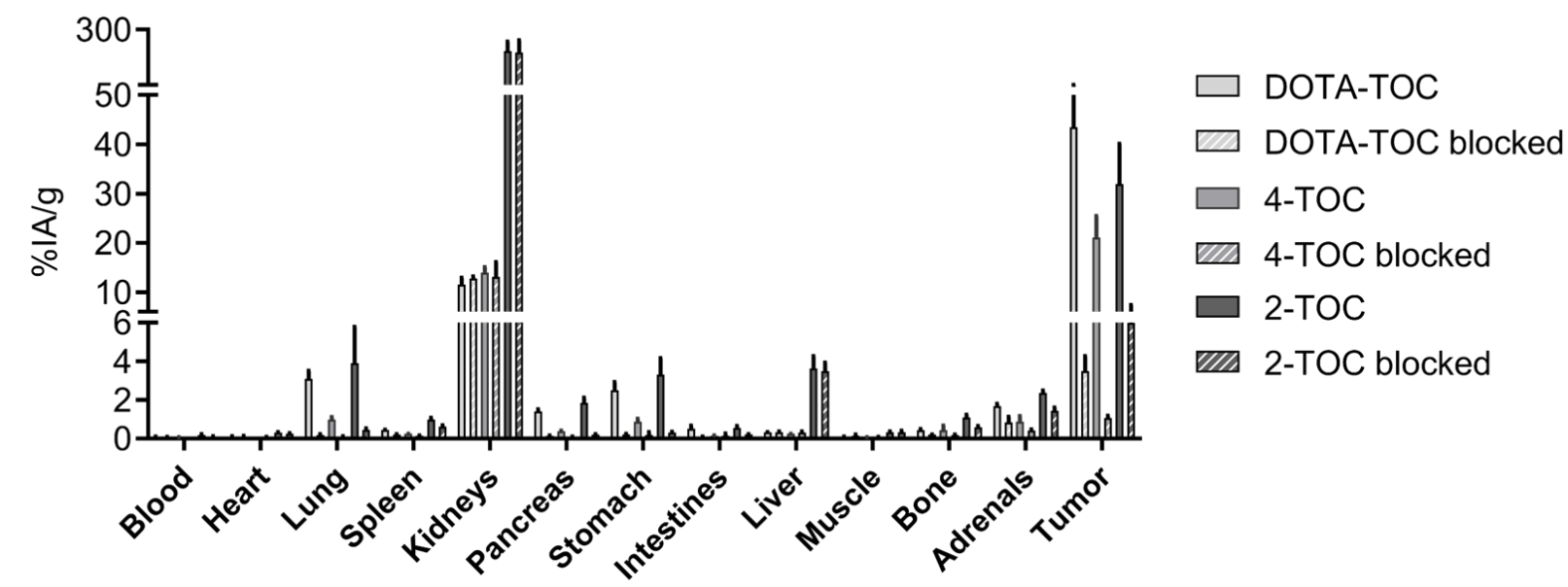

Figure S8 Biodistribution of ${ }^{177}$ Lu-labelled octreotide analogues $4 \mathrm{~h}$ post-injection in $\mathrm{CHO}-\mathrm{hSstR}$ 2a tumour-bearing SCID mice. The values represent the mean \pm standard deviation of at least three animals in \% injected activity per gram of organ. $10 \mathrm{pmol}$ of radioligand per animal were applied by i.v. injection. For blocking studies, the animals additionally got an application of $30 \mu \mathrm{g}$ unlabelled DOTA-TOC. 